\title{
A new processing for improving permeability prediction of hydraulic flow units, Nubian Sandstone, Eastern Desert, Egypt
}

\author{
Osama M. Elnaggar ${ }^{1}$ (D)
}

Received: 26 March 2017 / Accepted: 5 December 2017 / Published online: 16 December 2017

(C) The Author(s) 2017. This article is an open access publication

\begin{abstract}
Fifteen surface sandstone samples of Late Cretaceous age were compiled from Wadi Kareem area in Eastern Desert, Egypt. Samples were subjected to permeability and porosity measurements to show their distributions and possibility of separating them into different hydraulic flow units. It is known that hydraulic flow unit is a volume of rock within a reservoir that has petrophysical and lithological attributes that affect flow properties and differ from those of surrounding units. It was found out that the normal application of Amaefule's hydraulic flow unit approach using the relation of normalized porosity index $\left(\phi_{Z}\right)$ versus reservoir quality index (RQI) and FZI values at $\left(\phi_{Z}\right)=1$ leads to deviation of predicted permeability from the measured one in case of scattered data of $\left(\phi_{\mathrm{Z}}\right.$-RQI) relation having a unit slope trend line. In the present study, the additional new processing leads to close matching between the measured and predicted permeability, hence reservoir description improvement. This is simply done through differentiation of all samples that lie on the unit slope trend line and those lie scattered on both sides of it, into three sub-flow units regardless their slopes and the use of (FZI) arithmetic average for each sub-unit instead of that at $\left(\phi_{\mathrm{Z}}\right)=1$. Permeability prediction has been improved after applying the new additional processing. Capillary pressure-derived parameters for some selected samples as micropores, mesopores, and macropores, used to support the new concept .
\end{abstract}

Keywords New processing $\cdot$ Permeability $\cdot$ Prediction $\cdot$ Flow units

\section{Introduction}

The Nubian Sandstone is applied to depict the terrigenous clastic sandstone sequence that overlies on the Precambrian rocks and underlies the Quseir variegated marine shale Formation of the Late Cretaceous age. Youssef (1957) stated that the Nubian Sandstone has been deposited under similar conditions and its age should be restricted to the Campanian; Said (1962) mentioned that the age of the Nubian Sandstone in Eastern Desert is generally thought to be of Late Cretaceous; and Soliman (1971) stated that all Nubian Sandstone ranges in age from Cambrian to Late Cretaceous and possess similar lithic characters. The Nubian Sandstone subjected to intensive studies by many authors, e.g., McKee (1962), Klitzsch et al. (1979), Ward (1979), Hassouba et al. (1988), EI Barkooky (1992), Darwish and EI Araby (1994), Ragab

Osama M. Elnaggar

osama_221@yahoo.com

1 Production Department, Egyptian Petroleum Research Institute (EPRI), Nasr City, Cairo, Egypt
(1994), Alsharhan and Salah (1995), and Abu Hashish (2004). The Nubian Sandstone has great economic importance due to its hydrocarbon potentialities and groundwater aquifers. Figure 1 displays the location of the studied section $\left(25^{\circ} 53^{\prime}-25^{\circ} 55^{\prime} \mathrm{N}\right.$ and $\left.33^{\circ} 22^{\prime}-33^{\circ} 25^{\prime} \mathrm{E}\right)$.

The generalized stratigraphic column of the Nubian Sandstone sequence in Wadi Kareem, (Abu Hashish 2004), shows that the outcrops are massive sandstone beds overlying the basement rocks and are described as cross-bedded sandstone interbedded occasionally with shaly and silty sandstone (Fig. 2).

The Nubian's results of porosity and permeability were processed according to Amaefule et al. (1993) to predict permeability, where a log-log plot of normalized porosity index $\left(\phi_{\mathrm{Z}}\right)$ versus reservoir quality index (RQI) yield a unit slop trend line, and the intercept value of this line at $\left(\phi_{\mathrm{Z}}\right)=1$ is called flow zone indicator (FZI), which is a characteristic parameter for each type of hydraulic flow unit that expresses specific geological and petrophysical attributes. The previous parameters are calculated using the following equations:

$\mathrm{RQI}=0.0314 \sqrt{ } k / \phi$ 


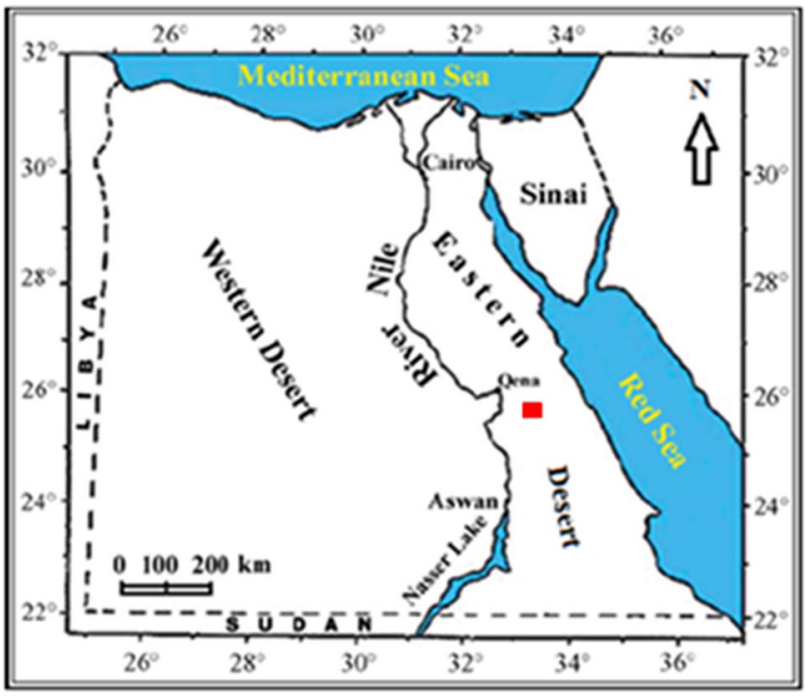

Fig. 1 Location map of the studied section, Eastern Desert, Egypt

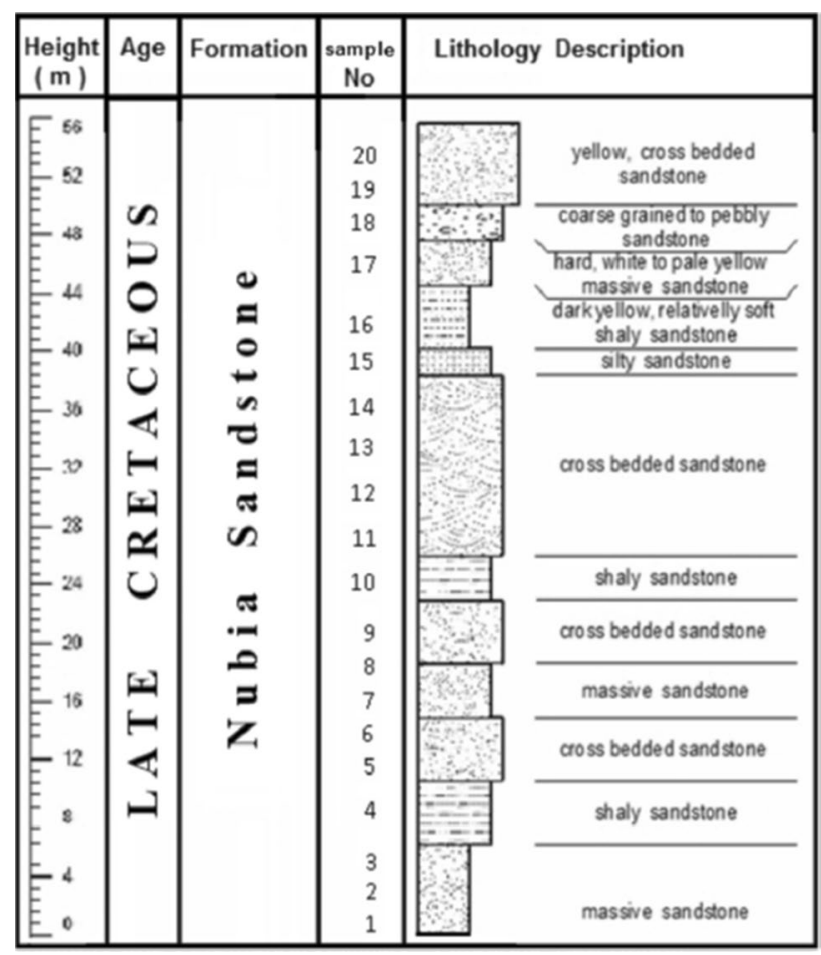

Fig. 2 Generalized stratigraphic column for the Nubian Sandstone sequence in Wadi Kareem, central Eastern Desert, Egypt (modified after Abu Hashish 2004)

$\phi_{\mathrm{Z}}=\left(\phi_{\mathrm{e}}\right) /\left(1-\phi_{\mathrm{e}}\right)$

$\mathrm{FZI}=\mathrm{RQI} / \phi_{\mathrm{Z}}$ where $R Q I$ is reservoir quality index, $(\mu \mathrm{m}), K$ permeability, $\mathrm{mD}, \phi$ effective porosity, fraction, $\phi_{\mathrm{Z}}$ normalized porosity, and $F Z I$ flow zone indicator.

In case of ideal $\left(\phi_{\mathrm{Z}}-\mathrm{RQI}\right)$ relation for a given hydraulic flow unit, all samples would be lie on or very close from the unit slope trend line, and then no scattering could be seen and FZI value that results from the intercept of the trend line at $\left(\phi_{\mathrm{Z}}\right)=1$, equals or nearly equals FZI arithmetic average of these samples (Eq. 3), and predicted permeability equals or is very close to measured one (actual), and hence the difference between them is the lowest. On the other hand, if all or majority of samples are scattered around the unit slope trend line, then (FZI) value from the intercept differs greatly from (FZI) arithmetic average of these sample, and predicted permeability is far from measured one, and the error between them is great. So the main idea of this work is to use (FZI) arithmetic average to improve the permeability prediction using hydraulic flow unit approach for the scattered samples around unit slope line of $\left(\phi_{\mathrm{Z}}\right.$-RQI) relation. Improvement is done through the new additional processing of Amaefule's approach by differentiation or redistribution of scattered samples of unit slop trend line of $\left(\phi_{\mathrm{Z}}\right.$-RQI) relation into three sub-flow units as follows:

1. Unit includes the scattered samples that lie above the trend line.

2. Unit for samples which lie directly on or very close from the trend line.

3. Unit encompasses the scattered samples that lie beneath the trend line.

The width or limits of the central unit (unit \#2) depend on how much the error or difference is reasonable or accepted between predicted permeability and measured (actual) one. For instance, if it is enough to get a predicted permeability represents $95 \%$ from the measured (actual) one, then the unit will cover all samples having this percent or more hence borders of this unit would be very close from the trend line. So the new simple idea is the use of (FZI) arithmetic average of each sub-flow unit instead of that produced from the intercept of the main trend line at $\left(\phi_{\mathrm{Z}}\right)=1$, to overcome the high difference between measured and predicted permeability using Eq. (4). Some of capillary pressure-derived parameters such as macropores, mesopores, and micropores were used to show petrophysical characters of the different sub-flow units. According to Amaefule et al. (1993), pores could be classified based on throat radii into, macropore whose throat size is more than $1.5 \mu \mathrm{m}$, mesopore whose throat size lies between 1.5 and $0.5 \mu \mathrm{m}$ and micropore whose throat size is less than $0.5 \mu \mathrm{m}$. Concerning micropores, they affect prtrophysical relations and defined as pores are less than one micron in diameter at least in one direction, Pittman (1971), or pores whose dimensions are smaller than 
those contributing to the rock's permeability according to Swanson (1985). Here pore sizes less than $0.5 \mu \mathrm{m}$ are used as a limit for microporosity values. The present study aims to improve the permeability prediction in uncored wells, using hydraulic flow unit approach but with new additional processing for the measured data.

\section{Techniques and materials}

All the measurements were carried out in EPRI-Core Analysis Lab. that belongs to Egyptian Petroleum Research Institute, where the studied samples were drilled into small cylinders of $2.54 \mathrm{~cm}$ in diameter and about $3 \mathrm{~cm}$ long for petrophysical measurements. These cylinders were cleaned and then dried using a drying oven. Porosity data were measured using matrix-cup helium porosimeter for grain volume evaluation and DEB-200 instrument that follows Archimedes law for bulk volume determination. Permeability measurements were done using steady-state air permeameter. Also, capillary pressure for some selected samples was done using mercury injection apparatus, where a clean and dry sample was loaded into a glass pentrometer consisting of a sample chamber attached to a cylindrical coaxial capacitor capillary stem. The sample and pentrometer assembly were loaded into the mercury injection instrument. The assembly was initially filled with mercury under a vacuum. Mercury is forced into the sample at low pressure, about 2.0 psia which is maintained until the equilibrium status is reached. The process was repeated through a range of pressures up to a maximum pressure of 30,000 psia. The volume of mercury injected at each pressure was determined by the change in capacitance in the capillary stem. The percent of unsaturated pore volume was determined as the percentage of pore spaces volume not filled with mercury.

\section{Results and discussion}

Porosity-permeability relation illustrates a high correlation coefficient $\left(R^{2}=0.80\right)$, as seen (Fig. 3$)$, but at the same time, we can easily detect the data scattering around the trend line. The scattering means presence of different pore systems and of course leads to the deviation of the predicted permeability from the measured (actual) one, if we handle all samples as a one group through this relation. Table 1 displays the measured values of porosity and permeability.

So it was necessary to classify the samples into zones to reduce the data scattering and improve the permeability prediction, and this was done through plotting $\phi_{\mathrm{Z}}$ versus RQI (Fig. 4), according to the approach of Amaefule et al. (1993), and hence we have three hydraulic flow units through three parallel unit slope trend lines, but the problem is deviation

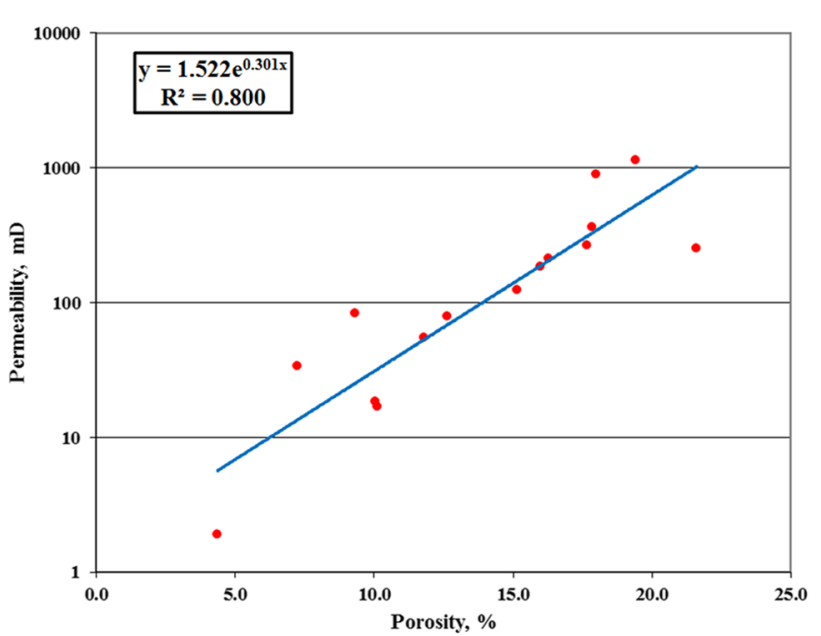

Fig. 3 Porosity versus permeability of the studied samples

Table 1 Porosity and permeability measured values of studied samples

\begin{tabular}{lrr}
\hline Samples & Porosity $(\%)$ & Permeability $(\mathrm{mD})$ \\
\hline 1 & 10.1 & 16.91 \\
2 & 10.1 & 18.24 \\
3 & 21.6 & 250.77 \\
4 & 4.4 & 1.89 \\
5 & 15.2 & 123.15 \\
6 & 11.8 & 54.73 \\
7 & 12.6 & 78.98 \\
8 & 16.0 & 184.14 \\
9 & 17.7 & 264.54 \\
10 & 16.3 & 209.49 \\
11 & 17.9 & 360.95 \\
12 & 7.3 & 33.76 \\
13 & 9.3 & 83.28 \\
14 & 19.4 & 1125.39 \\
15 & 18.0 & 893.68 \\
\hline
\end{tabular}

of predicted permeability using Eq. (4) than the measured one (actual) as seen in Table 2, and of course this is due to the data scattering around the trend lines for some flow units, especially units (1) and (3).

Predicted permeability was calculated using the following equation (Amaefule et al. 1993):

$K=1014(\mathrm{FZI})^{2}\left(\left(\phi_{\mathrm{e}}\right)^{3} /\left(1-\phi_{\mathrm{e}}\right)^{2}\right)$

where $K$ permeability, $\mathrm{mD}, F Z I$ flow zone indicator, $\phi_{\mathrm{e}}$ effective porosity, fraction.

Generally, it was found out that the predicted permeability differs greatly (Table 2) than the measured (actual) one using Amaefule's approach. Errors were calculated as follows: 
Fig. $4 \phi_{\mathrm{Z}}$ versus RQI of the studied samples (Reproduce with permission from Amaefule et al. 1993)

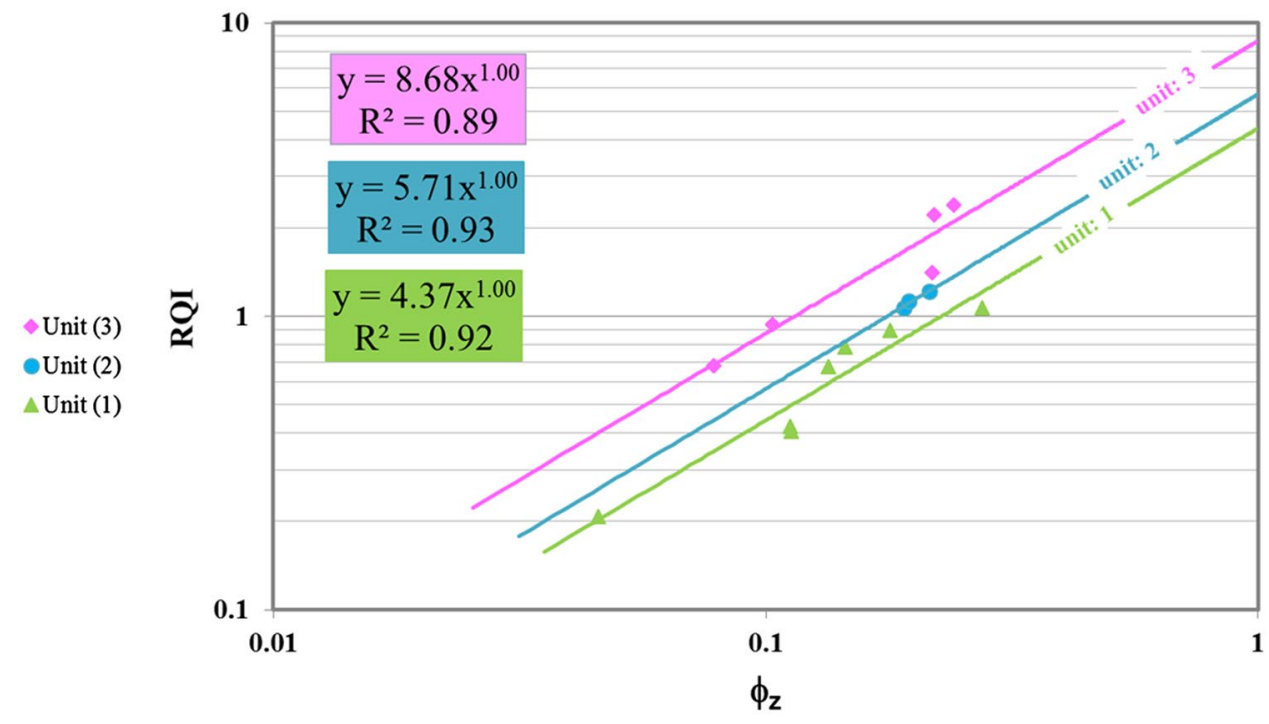

Table 2 Errors of predicted permeability using different methods

\begin{tabular}{|c|c|c|c|c|}
\hline $\begin{array}{l}\text { Units by } \\
\text { Amaefule } \\
\text { method }\end{array}$ & Samples & $\begin{array}{l}\text { Error, \% by } \\
\text { Amaefule } \\
\text { method }\end{array}$ & $\begin{array}{l}\text { Error, \% by } \\
\text { new process- } \\
\text { ing }\end{array}$ & $\begin{array}{l}\text { Units } \\
\text { by new } \\
\text { process- } \\
\text { ing }\end{array}$ \\
\hline \multirow[t]{7}{*}{ Unit 1} & 1 & -47.28 & -8.45 & \multirow[t]{3}{*}{ Unit 1-A } \\
\hline & 2 & -34.24 & 1.15 & \\
\hline & 3 & -26.95 & 6.52 & \\
\hline & 4 & 7.47 & 0.0 & Unit 1-B \\
\hline & 5 & 23.71 & -6.14 & \multirow[t]{3}{*}{ Unit 1-C } \\
\hline & 6 & 24.77 & -4.66 & \\
\hline & 7 & 35.09 & 9.69 & \\
\hline \multirow[t]{3}{*}{ Unit 2} & 8 & -4.34 & -3.08 & \multirow[t]{3}{*}{ Unit 2} \\
\hline & 9 & -1.84 & -0.61 & \\
\hline & 10 & 2.42 & 3.59 & \\
\hline \multirow[t]{5}{*}{ Unit 3} & 11 & -78.83 & 0.0 & Unit 3-A \\
\hline & 12 & -1.01 & -5.32 & \multirow[t]{2}{*}{ Unit 3-B } \\
\hline & 13 & 8.85 & 4.97 & \\
\hline & 14 & 23.45 & -1.39 & \multirow[t]{2}{*}{ Unit 3-C } \\
\hline & 15 & 25.57 & 1.41 & \\
\hline
\end{tabular}

Error $\%=(($ measured $(k)-$ predicted $(k)) * 100) /($ measured $(k))$.

Predicted permeability for all samples were improved to great extent (Table 2) using the new processing, except two samples (10 and 12) whose errors slightly increase. The predicted permeability of unit- 2 samples nearly did not suffer any significant change due to slight scattering of the samples that belong to this unit. Sample distribution using the new processing into sub-flow units is illustrated (Fig. 5).

The previous figure clarifies the following:

(a) Unit (1) using Amaefule approach (green) divided into three sub-flow units: 1-A, 1-B and 1-C. (b) Unit (2), central one (blue) remained nearly as it is because the data scattering is nearly absent.

(c) Unit (3) using Amaefule approach (pink) divided into three sub-flow units: 3-A, 3-B and 3-C.

Figures 6 and 7 display a comparison between the measured permeability versus the predicted one using Amaefule approach only and using the new additional processing successively. Table 3 displays another comparison between average values of porosity, permeability, FZI of original flow units using Amaefule's approach and those for the new related sub-flow units using the new processing of the studied samples.

It is noticed that (Table 3) the arithmetic averages of (FZI) values for sub-flow unit samples that lie on the unit slope trend line using Amaefule's approach are very close to (FZI) values at $\left(\phi_{Z}\right)=1$, (units 1-B and 3-B), so they have the lowest error percent in predicted permeability using Amaefule's approach, and the reverse is right for rest of the samples. Table 4 displays the average values of some of capillary pressure-derived parameters for some selected samples that represent the sub-flow units. The capillary pressure data (Table 4) according to Amaefule et al. (1993) show that for all sub-flow units within the original ones (units $1 \& 3$ ), micropores percent are greater for the rear part of original flow unit (samples having the lower values of $\phi_{\mathrm{Z}}$ and RQI, of course this is at the expense of the larger pores and this leads to tighter permeability but this property become reversed where macropores percent become prevailing for front part of original flow unit (samples having the higher values of $\phi_{\mathrm{Z}} \& \mathrm{RQI}$ ), so permeability improves. Decreasing in microporosity with increase in the normalized porosity may be irregular, that is it may be less or more than the required ratio that make data points lie on the trend line, consequently affect (RQI) and permeability 
Fig. $5 \phi_{\mathrm{Z}}$ versus RQI of the studied samples (sub-flow units)

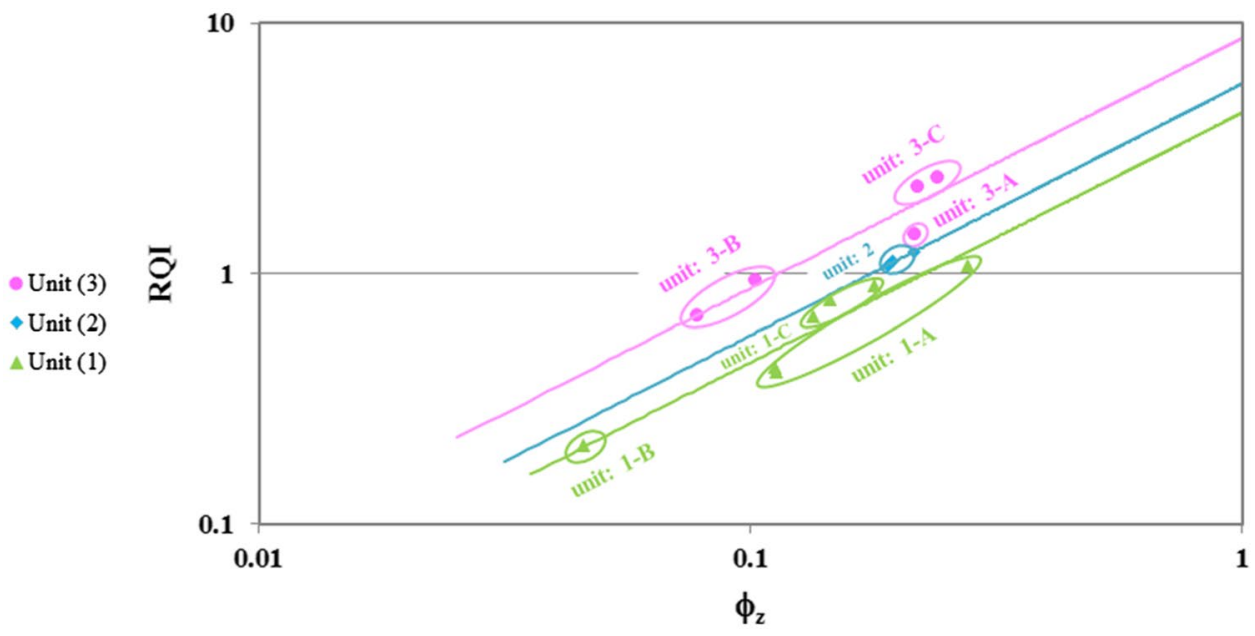

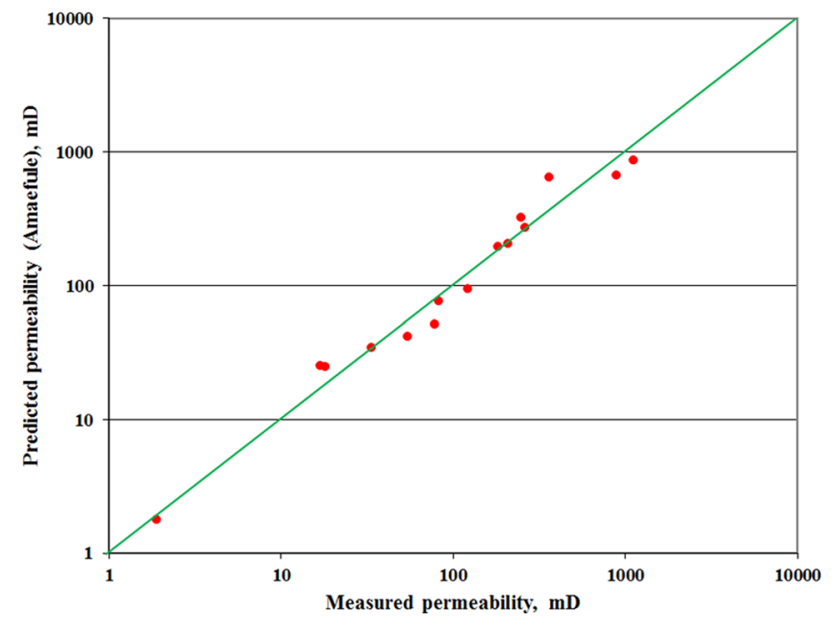

Fig. 6 Measured permeability versus predicted one using Amaefule' approach

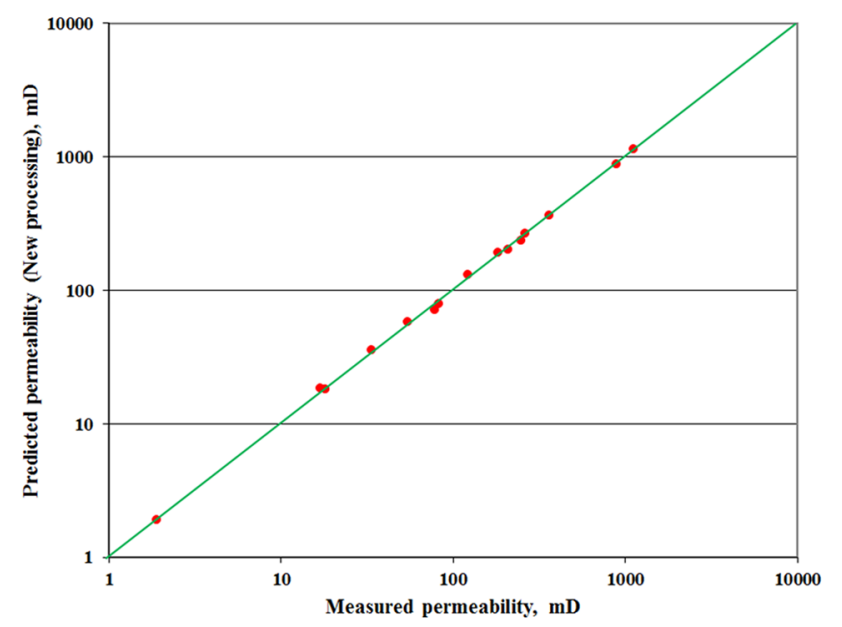

Fig. 7 Measured permeability versus predicted one using the new processing values and leads to data scattering above and beneath a unit slope trend lines as units (1-A, 1-C) and (3-A, 3-C). Behavior of mesopores type matches with that of micropores but less obvious. I think it would be beneficial to determine the different sub-flow units (using the current new additional processing) within a cored productive well then trying to extend this method to an uncored adjacent well that has same facies distribution like the cored well and within the same reservoir. The extending of the different sub-flow units of a cored well at specific depths to adjacent uncored well perhaps makes it possible to predict permeability at same depths using porosity logs. Also, the full understanding of the geologic history and diagenetic processes that affected the facies will be helpful for tracing the hydraulic flow units of interest within a reservoir.

\section{Conclusion}

Fifteen surface sandstone samples of Late Cretaceous age were compiled from Wadi Kareem area in Eastern Desert, Egypt. The studied samples subjected to permeability and porosity measurements and differentiated into different hydraulic flow units. The improvement of permeability prediction for a hydraulic flow unit could be achieved through a new additional processing for Amaefule's approach. For non-scattered samples, it is found that (FZI) value of a unit slope trend line at $\left(\phi_{\mathrm{Z}}\right)=1$ equals or nearly equals the (FZI) arithmetic average of those samples to a great extent, so FZI that produced at $\left(\phi_{\mathrm{Z}}\right)=1$ is recommended for non or very low scattered samples of $\left(\phi_{\mathrm{Z}}\right.$-RQI) relation for permeability prediction. Concerning scattered samples (FZI) of a unit slope trend line at $\left(\phi_{\mathrm{Z}}\right)=1$ differ greatly from the (FZI) arithmetic average of those samples. Partitioning the scattered samples of a unit slope trend line into sub-flow units leads to permeability 
Table 3 Average porosity, permeability, FZI of studied samples for different flow/subflow units

\begin{tabular}{|c|c|c|c|c|c|c|c|c|}
\hline \multirow[t]{2}{*}{ Amaefule units } & \multirow[t]{2}{*}{ Samples } & \multicolumn{2}{|c|}{ Average $\phi(\%)$} & \multicolumn{2}{|c|}{ Average $k, \mathrm{mD}$} & \multicolumn{2}{|c|}{ Average FZI } & \multirow[t]{2}{*}{ Sub-flow units } \\
\hline & & A. & S. & A. & S. & A. & $\mathrm{S}$. & \\
\hline \multirow[t]{7}{*}{ Unit 1} & 1 & 12.3 & 13.9 & 77.8 & 95.3 & 4.37 & 3.75 & Unit 1-A \\
\hline & 2 & & & & & & & \\
\hline & 3 & & & & & & & \\
\hline & 4 & & 4.4 & & 1.90 & & 4.54 & Unit 1-B \\
\hline & 5 & & 13.2 & & 85.6 & & 5.15 & Unit 1-C \\
\hline & 6 & & & & & & & \\
\hline & 7 & & & & & & & \\
\hline \multirow[t]{3}{*}{ Unit 2} & 8 & 16.7 & 16.7 & 219.3 & 219.3 & 5.71 & 5.67 & Unit 2 \\
\hline & 9 & & & & & & & \\
\hline & 10 & & & & & & & \\
\hline \multirow[t]{5}{*}{ Unit 3} & 11 & 14.4 & 17.9 & 499.4 & 360.9 & 8.68 & 6.49 & Unit 3-A \\
\hline & 12 & & 8.3 & & 58.5 & & 8.86 & Unit 3-B \\
\hline & 13 & & & & & & & \\
\hline & 14 & & 18.7 & & 1009.5 & & 9.99 & Unit 3-C \\
\hline & 15 & & & & & & & \\
\hline
\end{tabular}

$A$. Amaefule's flow units; $S$. sub-flow units using the new processing

\begin{tabular}{|c|c|c|c|c|c|c|c|c|c|c|}
\hline \multirow[t]{2}{*}{ Amaefule units } & \multirow[t]{2}{*}{ Samples } & \multicolumn{2}{|c|}{ Average RQI } & \multicolumn{2}{|c|}{$\begin{array}{l}\text { Average } \\
\text { micropores, } \\
<0.5 \mu \mathrm{m}\end{array}$} & \multicolumn{2}{|c|}{$\begin{array}{l}\text { Average } \\
\text { mesopores, } \\
0.5-1.5 \mu \mathrm{m}\end{array}$} & \multicolumn{2}{|c|}{$\begin{array}{l}\text { Average } \\
\text { macropores, } \\
>1.5 \mu \mathrm{m}\end{array}$} & \multirow[t]{2}{*}{ Sub-flow units } \\
\hline & & A. & S. & A. & S. & A. & S. & A. & S. & \\
\hline \multirow[t]{7}{*}{ Unit 1} & $1^{*}$ & 0.63 & 0.63 & 0.29 & 0.30 & 0.07 & 0.07 & 0.64 & 0.64 & Unit 1-A \\
\hline & 2 & & & & & & & & & \\
\hline & $3^{*}$ & & & & & & & & & \\
\hline & $4^{*}$ & & 0.20 & & 0.47 & & 0.14 & & 0.39 & Unit 1-B \\
\hline & $5^{*}$ & & 0.78 & & 0.20 & & 0.04 & & 0.76 & Unit $1-\mathrm{C}$ \\
\hline & $6^{*}$ & & & & & & & & & \\
\hline & 7 & & & & & & & & & \\
\hline \multirow[t]{3}{*}{ Unit 2} & $8^{*}$ & 1.13 & & 0.17 & & 0.02 & & 0.81 & & Unit 2 \\
\hline & 9 & & & & & & & & & \\
\hline & $10^{*}$ & & & & & & & & & \\
\hline \multirow[t]{5}{*}{ Unit 3} & $11 *$ & 1.52 & 1.41 & 0.32 & 0.26 & 0.03 & 0.04 & 0.64 & 0.70 & Unit 3-A \\
\hline & $12 *$ & & 0.80 & & 0.48 & & 0.05 & & 0.47 & Unit 3-B \\
\hline & $13^{*}$ & & & & & & & & & \\
\hline & $14^{*}$ & & 2.30 & & 0.19 & & 0.02 & & 0.79 & Unit 3-C \\
\hline & $15^{*}$ & & & & & & & & & \\
\hline
\end{tabular}

$A$. Amaefule's units; $S$. sub-flow units

*Capillary pressure samples prediction improvement, and the use of (FZI) arithmetic average for each sub-flow units for permeability prediction equation is recommended. Decreasing microporosity with increase in $\left(\phi_{\mathrm{Z}}\right)$ causes permeability and RQI improvement. 
Open Access This article is distributed under the terms of the Creative Commons Attribution 4.0 International License (http://creativecommons.org/licenses/by/4.0/), which permits unrestricted use, distribution, and reproduction in any medium, provided you give appropriate credit to the original author(s) and the source, provide a link to the Creative Commons license, and indicate if changes were made.

\section{References}

Abu Hashish MF (2004) Effect of diagenesis on petrophysical properties of sandstone rocks: a case study of the Nubia sandstone, Eastern Desert, Egypt. In: Proceedings of the 3rd international symposium on geophysics, Tanta, Egypt, pp 271-289

Alsharhan AS, Salah MG (1995) Geology and hydrocarbon habitat in a rift setting: Northern and Central Gulf of Suez, Egypt. Can Pet Geol Bull 43:156-176

Amaefule JO, Altunbay M, Tiab D, Kersey D, Keelan DK (1993) Enhanced reservoir description: using core and log data to identify hydraulic (flow) units and predict permeability in uncored intervals/wells. In: 66th annual SPE conference and exhibitions held in Houston, TX, October 3-6

Darwish M, El Araby AM (1994) Petrography and diagenetic aspects of some sliciclastic hydrocarbon reservoirs in relation to the rifting of the gulf of Suez. Egypt J Geol 3:25

El Barkooky AN (1992) Stratigraphic framework of the paleozoic in the Gulf of Suez Region, Egypt. In: Proceedings 1st conference on geology of Arab World, Egypt
Hassouba M, Mokhtar A, Sarawi M (1988) Petrographic and reservoir quality studies in Ramadan field" Nubia cross. In: Ninth E.G.P.C exploration and production conference, Cairo

Klitzsch E, Harmas JC, Lejal-Nicol A, List FK (1979) Major subdivisions and depositional environments of Nubia strata, southwestern Egypt. AAPG Bull 63:967-974

McKee ED (1962) Origin of Nubia and similar sandstone. Geol Rundschau 52:551-587

Pittman ED (1971) Microporosity in carbonate rocks. Am Assoc Pet Geol Bull 55:1873-1881

Ragab MA (1994) Petrophysical properties of the surface Paleozoic Nubia sandstone south west Sinai Egypt. In: 2nd international conference on geology of the Arab World, Cairo University

Said R (1962) The geology of Egypt" Amsterdam. Elsevier, New York

Soliman MS (1971) Reply to carboniferous 771 of Egypt. Isopach and lithofacies maps. Bull Am Assoc Pet Geol 55:893-896

Swanson BF (1985) Microporosity in reservoir rocks-its measurement and influence on electrical resistivity. In: SPWLA 26th annual logging symposium, 17-20 June, Dallas, TX

Ward WC (1979) The Nubia formation of Quseir-Safaga area, Egypt. Ann Geol Surv Egypt IX:420-431

Youssef MI (1957) Upper Cretaceous rocks in Quseir area. Desert Inst Bull Egypt 2:35-54

Publisher's Note Springer Nature remains neutral with regard to jurisdictional claims in published maps and institutional affiliations. 